\title{
МОВНА КАРТИНА СВІТУ М. ВІНГРАНОВСЬКОГО (НА МАТЕРІАЛІ ПОЕТИЧНОЇ ЗБІРКИ «НА СРІБНІМ БЕРЕЗІ»)
}

Городецька В. А. Мовна картина світу М. Вінграновського (на матеріалі поетичної збірки «На срібнім березі»).

У статті досліджено проблему індивідуально-авторської мовної картини світу M. Вінграновського, здійснено аналіз тематичного поля «Простір», у якому презентується неповторний погляд автора на рідну землю. 3'ясовано, що лексика на позначення просторових явищ формує 10 лексико-семантичних груп і відображає географічний простір усієї України $з$ детальним описом регіонів Наддніпрянщини та Північного Причорномор'я.

Ключові слова: мовна картина світу, індивідуально-авторське світосприйняття, тематичні поля лексики, лексико-семантичні групи.

Городецкая В. А. Языковая картина мира Н. Винграновского (на материале поэтического сборника «На серебряном берегу»).

В статье исследуется проблема индивидуально-авторской языковой картины мира Н. Винграновского, осуществляется анализ тематического поля «Пространство», в котором подается неповторимый взгляд автора на родную землю. Установлено, что лексика, обозначающая пространственные явления, формирует 10 лексикосемантических групп и отображает географическое пространство всей Украины с детальным описанием регионов Поднепровья и Северного Причерноморья.

Ключевые слова: языковая картина мира, индивидуально-авторское мировосприятие, тематические поля лексики, лексико-семантические группы.

Gorodetska V. A. Language picture of the world of M. Vingranovsky (based on poetry collection "On the silver bank").

The article is devoted to the issue of individual author's "language picture of the world" on the material of poetic speech of M. Vingranovsky. The thematic field "Space" in which the author presents a unique view to their homeland. The complex lexical analysis on the material of the collection of poems "On the silver bank" reveales that the thematic field is presented in ten lexical-semantic groups: "Place names", "Hydronyms" "The names of countries", "Exotic geographical names", "Landscape", "Soil", "Plants", "Water space", "Sky, space", "Building". The individual writing style of Ukrainian poet presents a unique world with only his realities based, of course, on the national language paradigm. M. Vingranovsky presents all Ukraine. Cities cover the state space from the West (Lviv as city of love which is associated for the artist with I. Franko and Prince Daniel Galician) to the East (Donetsk region), from the North (Kyiv) to South (Odessa), Center (Kaniv, a famed city for everyone due to the Ukrainian T. Shevchenko, Veseli Bokovenki, Kirovohrad region), the Crimea (Sevastopol) and Krivyi Rih (iron heart of the country). The poet creates an almost cinematic image of a united integrated country - Motherland, Ukraine, Ukrainian 
World to his own mind shared by the Ukrainians. The artist delights landscapes of fields, steppes, valleys, grasslands, deserts, ravines. Elements of industrial landscape - career, which is also a sign of the southern regions - are of great interest. These lands unite ways, paths not only in geographical sense, but also in the sense of life styles. Created landscape is complemented by forests, groves, plantings, gardens. Space poetic lines can not be imagined without the rivers Dnieper, Desna, Ros, Psel, Vorskla, Sula, Yatran. Lyman, situated in the south of Ukraine, takes the reader to the Black Sea and the Azov Sea, the lake Sivash. And in the center of the universe - simple and clear house with a yard and attic, fold, shop and school, threshold of family home and orphanage where the children, having become the victims of the war, live, and a window overlooking an unexplored way to the boundless sky.

Key words: language picture of the world, individual author's worldview, thematic fields of vocabulary, lexical-semantic group.

Проблема дослідження «мовної картини світу» була сформульована в мовознавстві ще у XIX столітті в лінгвофілософських працях В. фон Гумбольдта, який акцентував на тому, що мова пов'язана з оригінальним національним мисленням і світосприйняттям на кожному зі своїх рівнів, починаючи від фонетичної системи і завершуючи найвищим ярусом - граматичною організацією. У межах одного мовного колективу формується специфічний образ світу, що визначається національним характером і психотипом та впливає на систему духовних архетипів народу. Послідовники німецького науковця Л. Вайсгербер, який увів сам термін «мовна картина світу», Л. Вітгенштейн, М. Хайдегер, поетично називаючи мову «оселею духу», розвинули концепцію національномовної картини світу, зазначаючи їі динамізм, зв'язок з психологією й історією етносу та його мови. Соціокультурні універсалії, що презентують культуру народу загалом, сформувалися під впливом своєрідного бачення світу. Американські науковці Е. Сепір та Б. Уорф зазначали, що реальний світ сприймається кожним представником народу опосередковано через сформовані протягом століть концепти культури, яка реалізуються в мові. Серед вітчизняних фундаторів теорії можна назвати насамперед О. Потебню, який розвернув ідеї світової науки на національному грунті. У XX столітті спостерігається справжній ренесанс ідей В. Гумбольдта та О. Потебні, а аналіз проблеми «мовної картини світу» представлено у працях Д. Апресяна, К. Красовської, Д. Колшанського, Д. Лихачова, В. Маслової, О. Радченка, Й. Стерніна та інших, що свідчить про іiі актуальність. У науковій літературі трапляються поняття філософської, 
релігійної, художньої картини світу. Мовна картина світу аналізується на фонетичному, граматичному, зокрема словотвірному, матеріалі; залучаються навіть діалектологічні дослідження, у яких стверджується ідея специфічності світосприйняття носіїв однісї мови, що проживають на різних територіях. Якщо кожен народ презентує власне бачення реальності, то, варто передбачити, і кожен із носіїв мови як член мовного колективу, а особливо майстер художнього слова, у межах загальнонаціональної мовної картини світу формує своє неповторне світобачення, пов'язане 3 багатьма соціальними статусами (вік, освіта, стать, місце проживання, ментальний та психічний тип особистості тощо). Іншими словами, складається індивідуально-авторське бачення світу. На нашу думку, найбільш повне уявлення про мовну картину світу можна отримати, здійснивши аналіз матеріалу на лексичному рівні.

Отже, мета статті полягає у вивченні індивідуально-авторської «мовної картини світу» М. Вінграновського (на матеріалі поетичної збірки «На срібнім березі»), а також доведенні того, що в індивідуальній манері письма поета представлено цілісний український світ із тільки йому притаманними реаліями, які спираються, безумовно, на національне світосприйняття. Досягнення мети передбачає розв'язання таких завдань: дослідити тематичний розподіл лексики поетичного мовлення автора; окреслити мовну картину світу як прояв оригінальності світобачення та індивідуальної творчої манери митця.

Назвою поетичної збірки «На срібнім березі» М. Вінграновський окреслив важливість просторової характеристики для розуміння сутності його сприйняття світу. Тематичне поле «Простір» представлено лексемами, які можна розподілити за 10 лексико-семантичними групами (ЛСГ).

ЛСГ 1 «Топоніми»:

Севостополь (Гірка моя прискорена любов: / На світі Севастополів немає! / Постріляна і перебита кров / Мене далеко й довго обнімає);

Одеса (Лампачу насушим - шифер / На привозі десь в Одесі);

Канів (Я вже прошу судьбу - могікан / з могіканів - / Я вже човен в снігах. / Я в сніги вже гребу / Лиш Десна молода... / молодесенький / Канів...); 
Київ (Що гай з землі дивився $і$ стояв, / Що солов $\dddot{і}$ маліли, як морельки, / А Київ, мов шалений, цілував, / В степах село чиєсь, далеке i маленьке);

Холодна Балка (В Холодній Балці над лиманом / Нирки пірнають в золоте. / I Сіра Відьма крупним планом / Собі коханнячко плете);

Кривий Ріг (Душа моя в цзвітінні - i немає, / Нема извітіння більшого нема!.. / А снігодощ над вовком пролітає / I Ріг Кривий поволі обніма);

Веселі Боковеньки (А там за Ятранню - Веселі Боковеньки! / Poca, i cmen, і світлі снігурі);

місто-любов (Львів) (Моє місто-любове, нам з тобою священні / І світанок Данила, і вечір Франка).

\section{ЛСГ 2 «Країни»:}

Молдавія (Довго-довго давнє літо давніло, / Де не йшло - стояла синя мла. / Мамалижна хмара на Молдавію / Ще одну, рябеньку, повела);

Україна (Щаслився ж і иявіти, метелику малий, / На долю і на волю тополину, / Понад Дніпром, де сонце, де орли, / Понад Дніпром на світ, на Україну. / В білій льолі люлі / Спатоньки-спатулі, / Татомама, тато-мама / Цілували...);

Вітчизна (Де вітру синьо-голубий огин / Весінню під горою суиить глину, / Не надивлюсь на погляд дорогий, / На ияю свою нестомлену Вімчизну).

ЛСГ 3 «Екзотичні власні географічні назви»:

Цейлон (Як чорний чай, як чорний чай Цейлону, Мені цее літо впало у лиман...).

\section{ЛСГ 4 «Гідроніми»:}

Псло, Ворскла, Сула (На Псло, на Ворсклу, на Сулу, / На юні води непочаті / Ліг золотий осінній сум, / Поліг багрець у тихім святі / На Псло, на Ворсклу, на Сулу);

Десна (3 того боку снігів задиміла весна, / Білим димом снігів засиніло за Десну; Благословенні води літ, / Літа Десни благословенні, / I часу вічного політ / В однім осяянім іменні);

Ятрань (А там за Ятранню - Веселі Боковеньки! / Роса, i cmen, і світлі снігурі);

Рось (Минає все у плині дорогому.. / Під синіми вітрилами ночей / Вона тече старому і малому, / На все життя єдина Рось тече);

Сиваш (Я вас люблю, як сіль свою - Сиваш...).

๑) В. А. Городецька, 2016. 


\section{ЛСГ 5 «Ландшафт»:}

земля (могила, землянка) (Земля - могила для загиблих, / земля - землянка для живих; Земля на небі, вечір, щастя, дим, / Роки $i$ рік, сніги, водою стерті, / Вони мені одне лиш: ви $i$ ви...; Благословенна срібна твердь / Землі $і$ неба, дня і ночі; На віки вічні $i$ назавтра, Як і на вчора, як тепер, I мерзлу землю гріє ватра, - На ватрі вогник перемерх);

село (В невільнім вив'яленім літі, / Де в переліті вже крило, / Де сохнуть далі перемліті / I за селом сидить село, - / Мене окликнув xтось!..);

поле (Притихли далі охололі, / I висвист птичого крила / Затих над хвилею $і$ в полі, / I небо падає поволі / В холодній краплі із весла; $3 а$ птахом піниться вода. / В малому полі мак червоний / Пречисту хмару вигляда / І макоивітний погляд ронить);

степ (Дорогою століть в очах мого народу / Іде на вітрі чорноплечий степ; Моя ви пам'ять степу-ковили, Зорі червоний голос і свободи; Човни і ми в човнах стемніли, / Стемніла птиия на льоту, / Лище козацькі дві могили / Темніють довго у степу); Колесо котить себе. / В голосі колеса сухо. / Cтеп даленіє в рябе, / Дихає спеченим духом; Сміється заєиь з морквою за вухом: / Мокреньким носом ловить сніженя... / I пахне шишка біля себе сухо, / I степ лежить від мене - до коня...);

паша (Вологий запах, запах паші / В сухому сяеві стожсар. / Почав уже в багатті нашім / Дрімати жар, куняти жар);

дорога (Твоя дорога - / Мої там кроки, / I голос і луна, / Дитинна давнина / Все при мені; Зірно каже собі про дощ, / Про краплину малу на ньому, / Про чорнобил, і нехворощ, / I дорогу - назад додому; У кожної дороги - ноги. / I крок дороги - крок розлук... /Мені невидимі дороги - / Дороги снів твоїх і рук...; Блакитно на душі... забув, коли мовчав... / Вже гасли пальиі, билася дорога, / А тут тобі і нате: молочай / При березі, в камінні, на порогах..; Лии літо синіє до білих одеж, / Та буде, та буде дорога сивова; Зірно каже собі про дощ, / Про краплину малу на ньому, / Про чорнобил, i нехворощ, / I дорогу - назад додому; Лии літо синіє до білих одеж, / Та буде, та буде дорога сивова; Лии літо синіє до білих одеж, / Та буде, та буде дорога сивова; Заспіваю твоє ім'я. / Твоє тихе ім'я вишневе, / Де між хмарами обійма / Свою ніжну дорогу небо. / Де горить під зорею мак / I говорить гроза з грозою. / Переманює - перейма 
/ Хвиля хвилю попід горою. / Заспіваю твою любов / У великій твоїй дорозі, / В тій дорозі, де й я ішов / В кароокій рясній тривозі, / Де иілує росу роса, / Де дніпрова світанна повінь / I на ластівиі не згаса / Молодий вечоровий промінь; Але душа моя затерпла - / Відкрилась голосом отим / Дорога біла середстепна, / Де йшлось великим і малим...);

стежка (I стежка вже не лащиться під ноги, / I не співає каркає лиш птах... / Взуваймось добре на свою дорогу, / Вдягаймось тепло на зимовий илях);

шлях (Чи то було мені, чи снилося мені - / Синіли грущі, грущі чи смереки, - / Як чорнобривий шлях у срібному вікні / Проліг мені із коником сивеньким);

пустелі (Течіть, народи многоликі, / Поміж пустель, степів, дібров, / Із нами намі мудрі ріки - / Надія, віра і любов);

долина (Прозорий холод гір не покидав, / Лежав на ліктях у долинах морок);

луг (На маленькій планеті у великому лузі / Сходить вечір на сине, на сизе й сумне);

гори (На міднім небі вечір почорнів, / Малі, без голосу, у ніч летіли птиці. / Згори гора дивилась у черлінь, / I хилитався човен до човнищі; Прозорий холод гір не покидав, / Лежав на ліктях у долинах морок);

береги (Повідтуманіли береги, / Понанахилились обереги, / Глянули з-під інею луги, / Як вставає місяџь обережний);

яри (Ярами бурими, гнідими / Тумани впали й поповзли);

руйновища (Лежать руйновища. Затихли);

кар'єр ( $А$ тим часом старе горе / Вже по-свому хазяйнує: / Молотком дорогу мостить, / Возить щебінь із кар'єру, / Дітям тудзик пришиває, Через яр до школи водить).

\section{ЛСГ 6 «Грунт»:}

пісок (Дивно на піску / Лежали тіні легкобоко...);

глина (Подовшали тривоги $і$ листи, / Ліси на глину, на пісок опали;3-поза чого, з далекого незгоддя / Заснув у глині шумерійський cepn).

\section{ЛСГ 7 «Рослинні насадження»:}

ліс (Подовщали тривоги і листи, / Ліси на глину, на пісок опали);

сад (Відчорніли в саду переспілі пасльони, / Ззимували сніги ув обійми ріки...; Зимовий сад під вороном білів. / Стояли очі у вікні сухому. / Смеркалося. Година йшла на сьому. / Життя лежало тихо, як посів);

() В. А. Городецька, 2016. 
діброва (Спи і слухай: вітер шаста / То в діброви, то з дібров...); гаї (В холодні землі взулися гаї / I стали біля неба, як стояли);

посадки (Риплять під інеєм останні капусти, / Стручки акащії тремтять уздовж посадки);

комиші (Пришерхла тиша - сіра миша - / У жовто-білих комишах. / I попелясто від кошар / Вівці копитце землю пише. / Пришерхла тиша - сіра миша - / У жовто-білих комишах, / I сизий цап - іранський шах - / Пришерхлу тишу тихо лиже).

ЛСГ 8 «Водний простір»:

лиман (На сірім мурі чорний кіт / Крізь білі вуса парко диха, / 3 а ним лиман синіє стиха - / Синіє осені приліт); (Дрімає вітру срібна дуда, / I дика груша в сні дичить. / Лиш не ляга моя приблуда, / Лиманом з поля ідучи); (Вийшла з дому зоря й піднімає вітрило, / Степ з лиманом лягли - ждуть вітрило зорі; Над лиманом білять синім, / Білять білим над лиманом, / Над лиманом кукурудза / Світлі вуса опустила; Дві дитини плачуть в люльиі - / Тато з мамою сміються. / A під хатою $з$ лиманом / Дід із прадідом бухика: / Душать гроно винограду - / Зимувати иілу зиму; Пасе кози над лиманом / В сіре вдягнена прабаба. / Баба - та копа картоплю / Й відганя бджолу від вуха); Та і я роблю тут дещь, / Правда, діло несерйозне, / Бо люблю щзось недалеке, / Бо своє люблю при собі, / Як любив його і вчора, - / Синій побіл над лиманом, / Сірий глід з гніздом сорочим, / Срібне слово павутини!; А тим часом над лиманом / Почорніло щзось і згасло, / Перебігло щзось дорогу, / Холодком перейнялось, - / I за руку старе горе / Веде горе молоденьке, / Веде горе попід гору / Від лиману полинами; А тим часом над лиманом / Чорт зубами тягне хмару, / Другий ззаду підпихає, / Тягнуть хмару на прабабу / I над нею виливають. / Та, тікаючи, прабаба - / Зі своӥми кізьми в скирту - / 3 хлібом синю ичиулину / На пеньках жує чорненьких!; Колисало небо / Білу хмару...);

море (Нас пам'ятає хліб: Дніпро тече про нас. / На краплю молиться всеокеанське море, / I мати біля груші, і вікно: / 3 руки із нашої себе зерно приоре, / Цілуєм колос - илях свій ведемо; А там за ними море грає! / Шугають зорі до стожар! / I в попелястий сон лягає / Червоноокий тихий жар; Колисало море / Хвилю кару...; Світилися моря, мов сонечка рябі, / I кожне море мало по тривозі);

вода (Цвіркун сокиркою січе Весло з водюю, зими й весни; Лии я незчувсь, як стишилась хода, / Як простелився вітер за плечима, / I на 
слова мої дивилася вода / Кленовими осінніми очима);

річка (Шепоче дощ про тебе у траві, / Ріку читає сірими очима; I ріки з водами, і вечір за горою, / I ранку під горою течія...; Тремтіло в річки по боках / Тонке зелене диво).

ЛСГ 9 «Небо, космічний простір»:

небо, небеса (Бринзою пахне роса, / В меду злипаються очі. / Бог прикотив небеса / Темною хмарою з ночі. / Позахолодало на ріллю, / На ріллю, де енко-снко-венко, - / Подивилось небо крізь зорю, / Як морозить хвилю морозенко; Коло тебенько я - дивись! / Ходять хмари нехмарним небом, / По воді сон зорі повивсь / Біля тебенько, коло тебе. / Коло тебенько я - за всіх. / А як ні - за одне лиш небо... / Збився з ніг золотий поріг / Біля тебенько, коло тебе; Високий иввіт небес біля мого народу, / Високий синій извіт між хмарами іде...);

зоря (Дрімає небо, і тече / Дорога зір на давню Десну);

Місяць, Земля (Щось далечі було... терново світ наливсь... / Земля і Місяць вдвох дивились око в око);

ЛСГ 10 «Будівлі»:

поріг (Який поріг? - Нема порога);

вікно (Нас пам'ятає хліб: Дніпро тече про нас. / На краплю молиться всеокеанське море, / I мати біля груші, і вікно: / 3 руки із нашої себе зерно приоре, / Цілуєм колос-илях свій ведемо; Ми сядемо за хліб, $і$ за вино, / I за вареники з картоплею пухкою / I за чарчиною хмільного супокою / Згадаємо чиєсь сумне вікно);

хата ( проводжати, / Мене проводжати та не забувати...);

подвір'я (А на весну козенятко / Розчепірить в хаті ніжки / Й застрибає по подвір'ю / По калюжі вдвох з собою);

кошара (Пришерхла тиша - сіра миша - / У жовто-білих комишах. I попелясто від кошар / Вівиі копитце землю пише);

школа, крамниця ( ш тим часом старе горе... / Тягне сіті із лиману, / В'ялить глосики з бичками, / Квасить в діжиі помідори, / Куфайки несе з крамниці...).

Просторова парадигма М. Вінграновського презентує всю Україну. Міста охоплюють простір держави від Заходу (Львів, місто серця, кохання, пов'язане для митця 3 іменами I. Франка та князя Данила Галицького) до Сходу (Холодна Балка, Донецька область), від Півночі (Київ) до Півдня (Одеса), Центр (Канів, знакове місто для

() В. А. Городецька, 2016. 
кожного українця у зв'язку із Т. Шевченком, Веселі Боковеньки зі знаменитим Давидівським парком, Кіровоградська область), Крим (Севастополь) і Кривий Ріг (залізне серце країни). Поет створює майже кінематографічну картинку однієї цілісної єдиної країни Вітчизни, України, не розділяючи у власній свідомості цей простір українського світу, де Київ як столиця і маленьке село біля великого лугу - разом на маленькій планеті. Із чужого світу представлено близьку Молдавію та далекий екзотичний Цейлон. Будучи уродженцем Миколаївщини, митець уподобав ландшафти полів, степів, долин, лугів, пустель, ярів. Вражаючими вкрапленнями $\epsilon$ елементи промислового пейзажу - кар'єри, що також $є$ ознакою південних регіонів. Усі ці землі об'єднують дорога, шлях, стежина як у географічному розумінні, так $\mathrm{i}$ в сенсі життєвих напрямів. Створений краєвид доповнюється лісами, дібровами, гаями, посадками, садами. Простір у поетичних рядках не можна уявити без павутиння річок Дніпра, Десни, Росі, Псла, Ворскли, Сули, Ятрані, iз зеленим чудом і комишами на берегах, що формує нашу уяву про мальовничу Україну. Річки Псло і Сула протікають на землях Сумщини, Ворскла - на Полтавщині, Ятрань - на Черкащині, Десна на Чернігівщині. Усе це притоки Дніпра, що входять до акваторії Чорного моря. У поезіях митця згадуються видатні діячі української культури, деякі географічні назви $€$ культурологічно значущими, наприклад, Десна як джерело таланту О. Довженка. Лимани, поширені в Україні на півдні в гирлах річок, які впадають до Чорного та Азовського морів.

I в центрі цього Всесвіту - прості та зрозумілі кожному хата 3 подвір'ям i горищем, кошара, крамниця i школа, рідний поріг батьківської оселі й дитячого будинку, у котрому знайшли притулок згорьовані діти війни, і вікно, звідки відкривається несподіваний шлях до безкрайого неба, зір та космосу.

Отже, картина світу поета відображає все те, що близьке серцю кожного представника нашого народу. Як майстер художнього слова, автор відтворив неповторний світ нашої батьківщини, нашого берега любові, чистого, рідного, срібного.

\section{Література}

1. Андрухович А. А. Языковая картина мира как концепт / А. А. Андрухович // Вісник Харківського національного університету імені В. Н. Каразіна. - Харків, 2010. 
- № 910. - Ч. I. - C. 90-95.

2. Березович Е. Л. К этнолингвистической интерпретации семантических полей / Е. Л. Березович // Вопросы языкознания. - 2004. - №6. - С. 5-25.

3. Биль О. Н. Национально-культурная специфика наименования пространства в поэтическом слове К. Бальмонта, В. Брюсова, М. Волошина, Н. Гумилева / О. Н. Биль // Вісник Харківського національного університету імені В. Н. Каразіна. Харків, 2010. - № 910. - Ч. І. - С. 262-267.

4. Вінграновський М. На срібнім березі. Збірка поезій [Електронний ресурс] / M. Вінграновський. - Режим доступу : http://umka.com/rus/catalogue/songbooks-notespoetry

5. Гумбольдт В. фон. Избранные труды по языкознанию / Вильгельм фон Гумбольдт ; [пер. с нем. Г. В. Ранишвили]. - М. : Прогресс, 1984. - 397 с.

6. Іовхімчук Н. Мовний образ дороги в українській народній пісні / Н. Іовхімчук // Науковий вісник Чернівецького університету. - Вип. 659. Романослов'янський дискурс. - Чернівці, 2013. - С. 165-168.

7. Потебня О. О. Думка й мова (фрагменти) : Слово Знак Дискурс Антологія світової літературно-критичної думки XX ст. / О. О. Потебня ; [за ред. М. Зубрицької]. - Львів, 1996. - 238 с.

Стаття надійшла до редакиії 22.11.2015 p. 